\title{
五感活用のすすめ* \\ Encouragement of Practical Use of the Five Senses
}

\section{青木三策** \\ Sansaku AOKI}

昔の話で恐縮である，戦災の焦土に復興の桘音が響き始 めた 1948 年の春, 私は学空を出, 商工省機械試験所に就 職して軸受研究室に配属され, 国産転がり軸受の品質向上 を図れという課題を与えられた。戦後の日本の軸受業界は 軍需という莫大な用途を一挙に失って不況の極みにあった し，品質・コストとも外国製品に劣っていた。民需に新し い活路を探し出すためには産官協同で需要掘起こしや技術 開発を行うことが急務であった。

戦前の沉用電動機には滑り軸受が使われており, 手差し の給油が必要だし, 始動時の動力損失も大きかった。転が り軸受への切換えは電動機の側からも望ましいし，転がり 軸受にとっても喉から手が出るほどの貴重な用途であっ た。ところが滑り軸受では比較的厚い油膜を介して軸が滑 って回るので静肃であるのに対して，当時の国産玉軸受は かなり耳障りな騒音を発した。外国製の玉軸受は比較的音 が小さいが，それでもある条件で回転するとシャーと鳴 く．国産品はジャーと喚く．これでは電動機に使ってもら えないので，騒音の原因究明と対策に挑んだ.

当時は軌道面の凹凸の概念が正しく理解されておらず， 表面粗さと真円度だけしか知られていなかった。音の大き い軸受と小さい軸受の表面粗さと真円度を測定してみても 大同小異で音との間に相関は認められなかった。そのころ は軌道輪を研削した後，目の細かいサンドペーパーを巻き つけた丸棒を回転する軌道輪に押しつけてポリシングで仕 上げていたので，表面粗さは輝くほどにきれいであった。

ひょんなことから騒音の発生原因が見つかった. 音を計 る前に軸受をきれいに洗浄しなければならないが, 当時の 研究室には超音波洗浄機などはなかったので, ボウルの中 の洗浄液に軸受を浸して洗っていた. 左手の人差し指に軸 受の内輪をはめ(内径が $17 \mathrm{~mm}$ だったのでちょうどよかっ た), 右手で外輪を勢いよく回転させて液の中で洗う.外輪 の回転が速いときは感じないが, 液から出して回転が遅く なり,止まる寸前になると指にコリッコリッという感じが 伝わってくる.この感じ方が明らかに音の大小と関連があ りそうに思えた.工学的にいえば低速時の摩擦トルクの変 動が騒音に関係があるのではないかということである.

そこで軸受が水平になるように内輪をピアノ線でつる し, 外輪におもりをのせてゆっくり回転させたときのピア

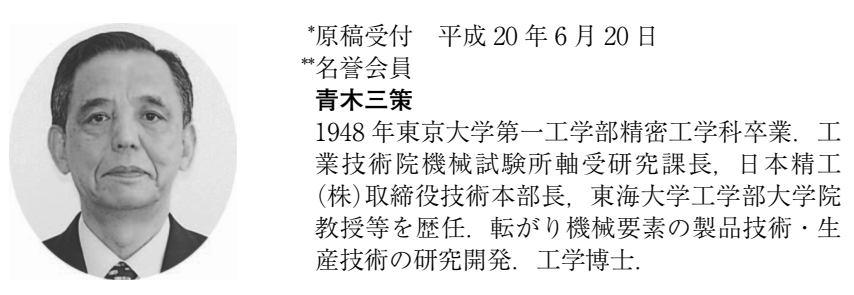

ノ線のねじれを, ピアノ線に貼りつけた小さな鏡に当てた 光の反射で測定し, 時間による変動を記録してみた。その 結果, 記録紙上のねじれの変動の振幅は音の大小とほぼ比 例関係にあり, その変動の周期から軌道上にピッチが 0.2 2 mm の凹凸があるらしいことが推察された. 次に粗 さ測定機に手を加えて触針の先端に鋼球を付け，一円周の 凹凸を記録したところ, 予想通りのピッチの凹凸の存在が 認められ，その高さは軸受によって異なるが $0.3 \sim 0.9 \mu \mathrm{m}$ で，音の大小とよい相関があることが分かった。今でいう ところのうねりである。研削盤の振動によって研削時に発 生し，前述のポリシングでは除去できない凹凸であった。 電動機に玉軸受が使われていなかったとか, 表面のうねり を知らなかったとか今から思えば馬鹿みたいな話である が，それが当時の現実だった。

同じころ, 機械試験所の名古屋支所で開発された玉軸受 軌道面用超仕上げ法がうねりの除去に効果があることが分 かり，騒音を低減できることも実証された。前述の音の感 じでいえばサーになった。 ポリシングではうねりの凸の部 分も凹の部分も一様に磨いていたのに対し, 結合度の低い 超仕上げ用のスティック砥石は軌道面の凸部直径の円にな じみ, 凸の高い部分だけを削るのである. 研削された軌道 面にこの砥石を当てて軌道輪を回転して途中で止めると, 上述のピッチの軸方向の縞が生じている。うねりを目で見 ることができたのである.

この結果に基づいて 1952 年ごろから軸受メーカの生産 ラインにこの超仕上げ技術が採用され，国産玉軸受の音響 品質が飛躍的に向上して電動機にも使用されるようになっ た. 軸受メーカでは生産技術に対してその後も探究が続け られ, 現在では外国品をはるかに凌ぐ評価が得られてい る.

転がり軸受の音響品質向上の発端はうねりの発見であ り，指先の触感から始まったともいえる、私の研究室での 仕事や, その後の生産現場・開発現場などでも五感を働か せて問題の解き口を見いだした事例を数多く体験してい る. 人間の頭は各種の情報を取り込んで思考を組立てる機 能をもっているが, 自分の五感から直に訴えられる情報に 対して最もよく反応し, 適格な判断が下せるようにできて いるのではないだろうか. 五感の方も, 自分が送った情報 が役立ったと思えば一層励みが出て研ぎ澄まされるであろ う.

五感の次にあるといわれる第六感はいわばひらめきの感 覚であり，これこそ創造的技術活動の源泉ではないだろう か. 五感を活用し, 第六感を培う日常の訓練は技術的能力 の育成に効果が大きいだけでなく, 人生を数倍楽しく生き る秘訣につながるようにも思われる。 